\title{
Determinants of Firm-Level Voluntary Corporate Disclosure in Emerging Markets: A Meta-Regression
}

\author{
Analysis
}

Kaihula P. Bishagazi (PhD)

Faculty of Economics and Business Administration, Saint Augustine University of Tanzania

(SAUT), PO Box 307, Mwanza, Tanzania

Received: Jun. 2, 2021 Accepted: Aug. 2, $2021 \quad$ Online published: Feb. 17, 2022

doi:10.5296/jpag.v12i1.19562ＵRL: https://doi.org/10.5296/jpag.v12i1.19562

\begin{abstract}
The purpose of this paper is to determine which factors are most important in voluntary corporate disclosure at firm level in emerging markets. The study characteristics that cause differences in results in the original empirical studies are also examined. This study applies a meta- regression technique developed by Stanley and Jarrell (1989) to a sample of 32 empirical studies published between 2011 and 2020. The study findings reveal that the financial crisis variable, region of the study variable, and weighting of the dependent variable significantly affect study results of the original empirical researches. Moreover, the most important and robust determinants of corporate disclosure in emerging markets are board independence and foreign listing status. Study findings also indicate that firm size, which is identified by most empirical studies to be a significant and most robust determinant of corporate disclosure, to be insignificant in this meta-regression study. This study will help to resolve the ambiguity that has existed over the past decade in literature as to which factors are really important in voluntary corporate disclosure practices in emerging countries. Secondly, this study extends the literature relating to corporate disclosure practice in emerging countries.
\end{abstract}

Keywords: firm-level, emerging markets, corporate disclosure, meta-regression

\section{Introduction and Motivation}

Emerging markets contribute to $2 / 3$ of the annual World's GDP and thus are major drivers of global growth (Elkhishin \& Mohieldin, 2020). Therefore, when business companies in emerging markets fail causing a series of financial crises, determinants of voluntary corporate disclosure such as firm size, profitability and board independence, spark major interest and debates among scholars and policy makers (Desta, Bishagazi \& Kifle, 2019). Poor corporate 
disclosure is considered as a major factor for decline in capital flows and given that the extent of voluntary corporate disclosure is low in emerging markets, research on its determinants will be a long standing source of debate (Hashim, Nawawi, \& Salin, 2014).

The significance of the research on determinants of voluntary corporate disclosure in emerging markets is further evidenced by the multitude of empirical work done in this area. To date about 100 country-specific empirical studies exist that discuss determinants of voluntary corporate disclosure at firm level in emerging markets over the last decade.

Although many factors have been identified, the empirical evidence is rather mixed and ambiguous. Moreover, the reported estimates of these determinants differ greatly in terms of both the statistical significance of the effect and their magnitude. Besides, it is definitely challenging formulating corporate disclosure policies by firms operating in emerging countries based on 120 factors identified by these empirical findings. It is now time to reflect on the real determinants of voluntary corporate disclosure so far identified by scholars rather than adding to the existing 100 studies with mixed results.

Thus, this analysis seeks to provide a comprehensive assessment of the empirical evidence accumulated over the past decade on the determinants of voluntary corporate disclosures at firm level in emerging markets. In doing so, the study aims at identifying factors that are most important in determining the extent of voluntary corporate disclosure in emerging countries and assesses the possible study characteristics that cause results in the original empirical studies to differ. Furthermore, the study identifies fruitful directions for future research.

To realize the above objectives this paper utilizes a meta-regression technique developed by Stanley and Jarrell (1989) on the sample of 32 empirical studies from 2011-2020 in order to integrate the divergent results from the primary models into one single value. This is the first study to apply a meta-regression analysis on empirical studies relating to corporate disclosure. It therefore compliments the meta analyses of Ahmed (1998), Ahmed and Courtis (1999), Khlif, and Souissi (2010), and Khlif, Ahmed and Souissi (2016).

The remainder of this paper is organized as follows: section 2 presents review of literature which includes the institutional framework for corporate disclosure in emerging markets, a theoretical framework and empirical evidence relating to determinants of firm-level voluntary corporate disclosure in emerging countries. Section 3 presents details of the methodology used while section 4 provides results of the analysis. Finally, section 5 presents the conclusion of the analysis and study limitations.

\section{Related Literature}

\subsection{The Institutional Framework for Corporate Disclosure in Emerging Markets}

The nuances of corporate disclosure are highly dependent on the jurisdiction in which an investor operates (Boubaker \& Nguyen, 2014). Most emerging markets have weak legal institutions for corporate governance and disclosure (Ntim, Opong, Danbolt, \& Thomas, 2012). Haji, Mohd, and Nazli (2012) presented evidence to show that the weakness of these legal institutions for corporate governance and disclosure had accentuated the extent of depreciations and stock market declines in the 1997 Asian financial crisis. 
In the aftermath of the 1997 Asian financial crisis, efforts to improve the quality of corporate governance and its disclosures in emerging market economies intensified. Most emerging countries adopted the Anglo-American institutional models of corporate governance and disclosure (Clarke, 2015). However, such formal Anglo-American institutional models did not operate as intended in most of the emerging markets. Even the largest publicly traded firms in these countries adopted the appearance of corporate governance mechanisms from developed economies, but these mechanisms rarely functioned like their counterparts in developed economies (Elkhishin \& Mohieldin, 2020). This resulted in informal institutions, such as relational ties, business groups, family connections, and government contacts, all playing a greater role in shaping corporate governance and its disclosure in emerging countries (Masum, Latiff \& Osman, 2020).

Due to the failure of the Anglo-American institutional models in emerging countries and the rise of informal institutions, concentrated family ownership became dominant. According to $\mathrm{Ji}$, Ahmed and Lu (2015), ownership structure is the crucial determinant of directions of corporate governance and disclosure practices in a given country. Almadi (2015) opines that ownership structure influences the nature of the agency problem, the agency costs, and the mechanisms available to minimize the agency problem.

It has been reported that there is greater dominance of family ownership in emerging markets. For instance, 67 percent of ownership structure in Malaysia is dominated by family ownership, whereas in Thailand, 62 percent of firms are family-owned (Lokman, Mula \& Cotter, 2014). In Taiwan 90 percent of total companies consists mainly of small- and medium-sized enterprises (SMEs) and family-control remains a dominant characteristic even in large corporations (Chantachaimongkol \& Chen, 2018). In Nigeria, 61 percent of family firms comprise of all businesses in the country (Dembo \& Rasaratnam, 2014). Moreover, according to Anggraini and Gurendrawati (2015), Indonesia followed by Singapore, have the highest concentrated family ownership in emerging markets. To date, concetrated family ownership has continued to be a stand-out characteristic of corporate governance and disclosure framework in emerging markets. This is because the transition of family owned firms to professional management is always difficult due to weak institutional environment . In essence, these firms attempt to appear as having 'crossed the threshold' from founder control to professional management. Nevertheless, the founding family often retains control through other (often-informal) means (Clarke, 2015).

This unique family ownership structure has led to a relationship based corporate governance regime, consequently, less transparency and disclosure of corporate information is expected. According to Clarke (2015), concentrated ownership combined with an absence of effective external governance mechanisms results in more frequent conflicts between controlling shareholders and minority shareholders.

To sum up, corporate disclosure mechanisms in emerging economies often resemble those of developed economies in form but not in substance. Consequently, informal corporate governance and disclosure mechanisms emerge to fill the corporate governance vacuum. 


\subsection{Theoretical Framework: The Agency Theory}

In a firm, the agency problem arises due to information asymmetry caused by the separation of ownership and control whereby the owner (principal) contracts the manager (agent) to run the corporation on the behalf of the owner (Jensen \& Mekling, 1976). Therefore, the main concern in the agency theory is the possibility of the manager to exploit the information asymmetry to act in a manner that is contrary to the interests of shareholders.

The Agency theory fosters the disclosure of corporate information as a way to control managers' actions and align incentives for managers and owners. It is often argued that in an effort of trying to convince shareholders that they are acting optimally, managers will voluntarily disclose information because they know that shareholders will seek to control their behavior through bonding and monitoring activities (Fathi, 2013).

Most of the empirical studies in this meta-regression analysis have used the agency theory to explain the interactions between corporate characteristics and voluntary corporate disclosure practices in emerging markets. The main reason for using this theory in these studies is that the agency theory best explains voluntary corporate disclosure in an institutional framework that is characterized by concentrated ownership, which is dominant in emerging economies.

According to Huber and DiGabriele (2021), the agency problem is centered on the degree of ownership concentration. When ownership is diffused, agency problems will arise from the conflict of interest between top managers and outside shareholders (Jensen \& Mekling, 1976). However, when ownership is concentrated, the nature of the agency problems shifts away the tension between managers and outside directors to the conflict between the large shareholders and minority shareholders ( $\mathrm{Ji}$, Ahmed \& Lu, 2015). This is because dominance of large shareholders may lead to expropriation of the minority interest, which is also known as tunneling (Geddes, 2020). This creates agency problem 2. It implies that the primary agency problem (agency problem 1) has broadened from mitigating the agency conflict of interest to protecting minority shareholders (i.e. investor protection) from expropriations by controlling shareholders and their management team (agency problem 2) ( Geddes, 2020).

Although family owned firms in emerging markets are associated with lower audit fees and less of agency problems, they have been blamed for suppression of minority rights which could adversely affect the economic development of these markets characterized by weak enforceability of legal and regulatory institutions (Cheng, 2014). In their empirical study, Tandiono and Hutagaol-Martowidjojo (2013) found that family firms face less severe type 1 agency problem (managers and owners). Instead, family firms face more rigourous agency problem of type 2 (conflict of interest between controlling and non-controlling shareholders). As a consequence, family firms are exposed to different types of agency costs such as altruistic behaviour, management entrenchment and shareholdrs expropiation.

Generally, voluntary corporate disclosure is highly related to agency theory and its assumptions, since it can be defined as a way to protect the shareholders' interests. Thus, the linkage between the problem (agency costs) and the potential solution (voluntary disclosure) is how effectively organizations deal with the concept of corporate governance (Chakroun \& 
Matoussi, 2012). Although, there are some controversies and unanswered questions related to the agency theory, it provides the structural platform and theoretical framework for voluntary disclosure decisions (Huber \& DiGabriele, 2021).

\subsection{Empirical Literature}

There has been a considerable debate in recent years about the need for better voluntary corporate disclosure in emerging countries. Previous studies have shown that good voluntary disclosure practices enhance corporate governance and reduces the likelihood of creative financial reporting arising from fraud or errors in emerging countries (Charumathi \& Ramesh, 2015). Building on the narrative surveys of the corporate disclosure determinants in emerging countries literature concerning the factors that may determine the extent of voluntary corporate disclosure in emerging countries; this section discusses the potential determinants that are considered important in voluntary corporate disclosure in emerging countries.

i) Board Independence: Empirical literature recognize board independence as an important determinant of voluntary corporate disclosure in emerging countries (Altawalbeh, 2020). For example, Jirouo and Chenguel (2014) show that a higher number of independent directors on boards leads to more effective board monitoring and higher levels of total voluntary corporate transparency. Particularly, Panditharathna (2019) provides evidence of the importance of the female directors in enhancing voluntary corporate disclosure. However, other researchers such as Damagum and Chima (2013) have established a negative association between board independence and the extent of voluntary corporate disclosure in emerging countries.

ii) Audit Committee: According to Kim, Taylor and Verecchia (2021), an audit committee is as an effective monitoring mechanism to improve the quality of voluntary corporate disclosure and reduce the agency costs. Several studies in emerging countries such as Khaldoon (2015) have found that the extent of voluntary corporate disclosure is positively associated with the presence of an audit committee.

iii) CEO Duality: CEO Duality exists when the Chief Executive Officer (CEO) is also the chairperson of the board at the same time (Fathi, 2013). According to the agency theory, CEO duality creates individual power for CEO that would affect the effective control exercised by the board (Al-Janadi, Rahman, \& Omar, 2013). In line with the agency theory, most studies in emerging markets support its argument by identifying a negative and significant effect between CEO duality and voluntary corporate disclosure at firm level (Qu, Philomena, \& Barry, 2013).

iv) Board Size: According to the agency theory, large boards are preferred as far as voluntary corporate disclosure is concerned because they play a crucial role in monitoring the board and in making strategic decisions and are less likely to be dominated by the management (Huber $\&$ DiGabriele, 2021). However, evidence of the effect of board size on voluntary corporate disclosure in emerging countries is quite mixed. For example, Damagum and Chima (2013) find a positive and significant relationship between board size and voluntary corporate disclosure. However, Charumathi and Ramesh (2015) conclude that board size has a negative effect on voluntary corporate disclosure because members of large boards are more likely to 
be less motivated to participate in strategic decision-making (i.e. the decision to increase voluntary disclosure).

v) Ownership concentration: Theoretically, Almadi (2015) argues that firms with a concentrated ownership structure are less motivated to disclose as long as the shareholders of these companies can obtain information directly from the company. In emerging markets, empirical studies such as Chakroun and Matoussi (2012) show that ownership concentration is significant and it negatively affects the extent of voluntary corporate disclosure at firm level.

vi) Firm Size: Firm size has proven to be one of the most important determinants of voluntary corporate disclosure in emerging countries (Nejla \& Haitham, 2017). The relationship between size and voluntary disclosure can be explained by the agency theory. The agency theory suggests that large firms have higher agency costs (Jensen and Meckling, 1976) and thus they will disclose more corporate information to reduce these agency costs (Lee, Lee \& Na-Eun, 2019). Although most studies in emerging markets show a positive correlation between firm size and voluntary corporate disclosure, there are few studies such as Chakroun and Matoussi (2012) which have concluded that larger firms have less voluntary corporate disclosure.

vii) Profitability: Literature in emerging countries show mixed results on the association between the extent of voluntary corporate disclosure and firms' profitability. Theoretically, the agency theory provides that higher profitability might induce management to supply more information to illustrate its ability to maximize the shareholders' value while firms with low profitability may feel threatened and wish to obscure poor results by disclosing less information (Forker, 1992). Researchers such as Abeywardan and Panditharathna (2016), have found profitability to be positively related to voluntary disclosure in emerging countries. On the other hand, Qu et al. (2013) show that profitability has no significance in determining voluntary corporate disclosure in emerging countries.

viii) Leverage: According to Jensen and Meckling (1976), highly leveraged companies incur more monitoring costs, and thus will seek to cut these costs by disclosing more information in order to satisfy the need of creditors. In emerging markets, most studies show that leverage is not a significant factor in determining voluntary corporate disclosure. For example, Foyeke, Odianonsen, \& Aanu (2015) argue that whether a company is highly indebted or not, will not change its attitude towards voluntary corporate discourse. Nevertheless, some few studies have concluded that leverage plays a significant role in voluntary corporate disclosure in emerging countries (Masum et. al., 2020).

ix) Foreign Listing Status: In foreign-held firms, it is more difficult for foreign shareholders to control managerial behavior not only because of the geographical differences but also due to barriers of language and culture (Kim et al., 2021). By and large, empirical studies on foreign listing as a determinant of corporate disclosure in emerging markets indicate a positive association between foreign listing status and the extent of voluntary disclosure of information (Ntim et al., 2012).

x) Audit Type: Empirical evidence on the relationship between audit type and voluntary 
corporate disclosure is rather ambiguous. In emerging countries, most of the empirical literature shows that although audit type has a positive effect on voluntary corporate disclosure, it is insignificant (Akhtaruddin \& Rouf, 2018). For example, Alturki (2014) found audit type to be positive but insignificant on total voluntary corporate disclosure. In contrast, Lan, Wang, \& Zhang (2013) found a significantly negative relationship between the extent of voluntary corporate disclosure and the audit type variable.

\section{Research Methods}

\subsection{Sample and Data Source}

This study meta analyses 32 studies out of 100 studies identified after doing an exhaustive and comprehensive search using search engines such as Econlit, JSTOR, ProQuest, and Google Scholar. The studies included in the sample are: (i) studies that apply regression models where the dependent variable (i.e. total voluntary corporate disclosure) is measured as an index, (ii) papers that report on beta coefficients and standard errors for each determinant of corporate disclosure, and (iii) studies that provide adequate statistical information on sample size, period of study, correlation coefficient, and coefficient of determination.

\subsection{Effect Sizes}

Effect sizes are the basis for meta-analysis. In fact, it is generally recommended that effect sizes should be reported in parametric inferential statistical analysis as this helps to show magnitude of the phenomena while controlling for the sample size (Stanley \& Doucouliagos, 2013). For this study, the effect size of beta coefficients of each of the ten determinants reported in the original studies are used. A sample of 32 papers selected produce 485 observations (i.e. beta coefficients). According Ankamah-Yeboah \& Rehdanz (2014), an average meta-analysis needs to use 92 estimates/ observations.

In order to calculate an average effect size for each study for each of the ten determinants, the analysis uses an approach of Hedges, Tipton and Johnson (2010) who discuss in detail the use of robust standard errors in a meta-regression analysis. An important feature of this estimator is that not only accurate standard errors are produced with as few as 10 to 20 studies, but also the estimator is unbiased for any set of weights (William, 2012).

\subsection{Model Specification}

This paper employs the following meta-regression model developed by Stanley and Jarrell (1989) so as to isolate robust determinants from the selected 32 studies. This model is represented by the following function:

$$
b_{j}=\beta+\sum_{\alpha k} Z_{j k}+e_{j} \quad \mathrm{j}=1,2,3 \ldots \ldots \ldots . \mathrm{L}
$$

where; $b_{j}$ is the reported estimate of $\beta$ of the jth study, $\beta$ is the true value of the parameter of interest, $Z_{j k}$ are the meta-independent variables that measure relevant characteristics of an empirical study, $\alpha_{\mathrm{k}}$ are the coefficients associated with those independent variables. 485 observations and 8 study characteristics/ explanatory variables have been analyzed in this 
study.

In addition, using the approach of Cuaresma, Hlouskova and Obersteiner (2008), the researcher employs Random Effects Maximum Likelihood (REML) method in this meta-regression analysis. However, following the argument of Rukhin et al. (2001), restricted REML is used instead of unrestricted REML because it may lead to biased estimators as it does not take into account the loss in degrees of freedom that result from estimating the mean of the population of scores $(\mu)$.

\section{Results and Discussions}

\subsection{Preliminary Tests}

In order to test whether the level of heterogeneity caused by study characteristics is significant, a quality effects model developed by Doi and Thalib (2008) is employed. Further, a methodological quality assessment list developed by Doi and Thalib (2008) to control for methodological quality is modified and applied.

Results show that significant heterogeneity exists between studies (i.e. $\mathrm{P}<0.001, \mathrm{I}^{2}=99 \%$ ). The pooled effect size is 0.89 (95\% CI, 0.68 to $0.79,32$ studies) implying that study characteristics have a serious effect on the results of the original empirical researches. We also carry out sensitivity analyses on these 32 studies. Although studies by Adelopo (2011) and Bhasin (2013) have a considerable percentage of weight in this meta-regression analysis, their exclusion does not seem have any significant impact on the results or heterogeneity (i.e. pooled $\mathrm{R}=0.73 ; 95 \% \mathrm{CI}=0.72$ to $0.74,29$ studies, $\mathrm{I}^{2}=98 \%$ ).

In addition, we test for publication bias in order to ensure that our sample of 32 studies is representative and unbiased. Apart from visually inspecting a funnel plot as shown in Fig. 4.2 above, we use the Egger's regression test. The intercept of the regression test is 0.019 (two-tailed p-value $=0.959$ ), signifying lack of evidence of publication bias in this meta-analysis. 


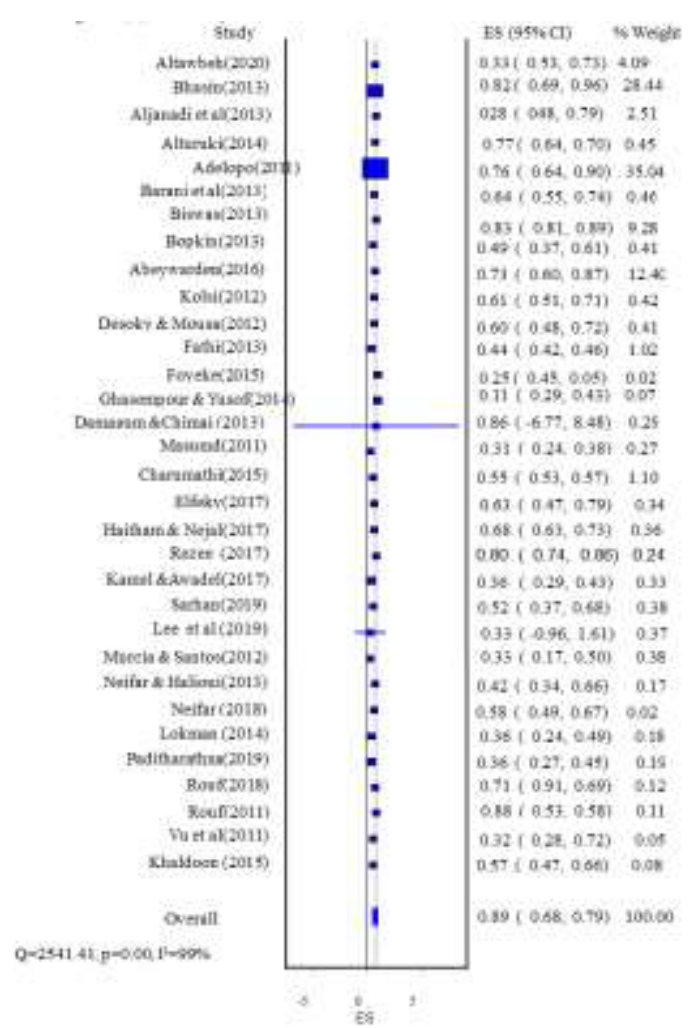

Fig 4.1(a) Quality effects model results

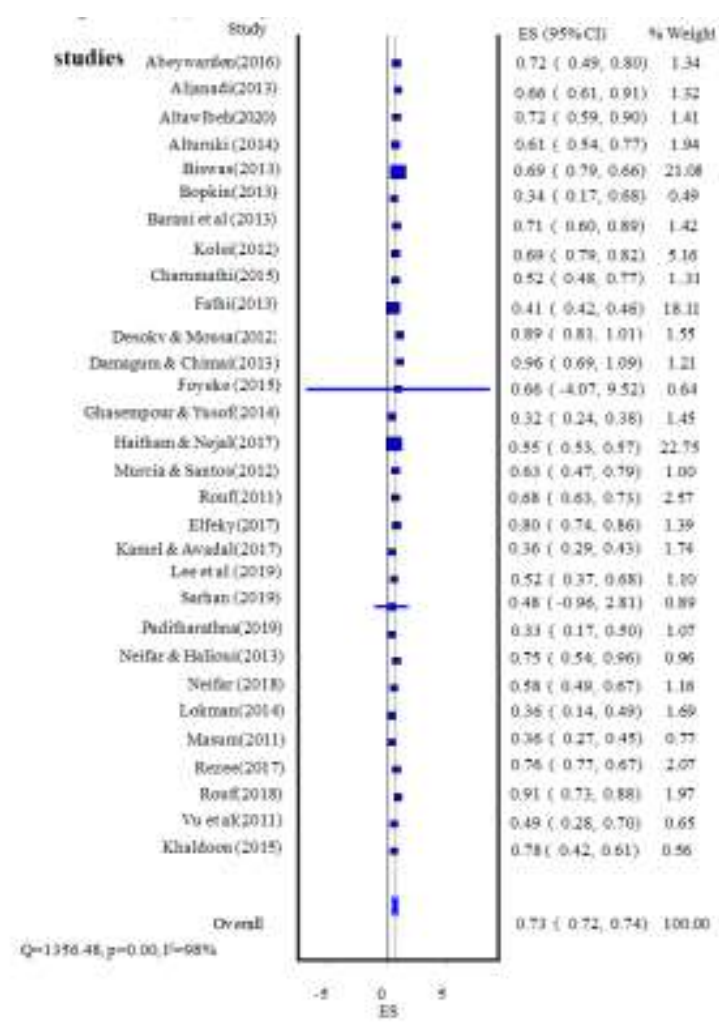

Fig 4.1(b)Quality effects model results after removal of some studies 


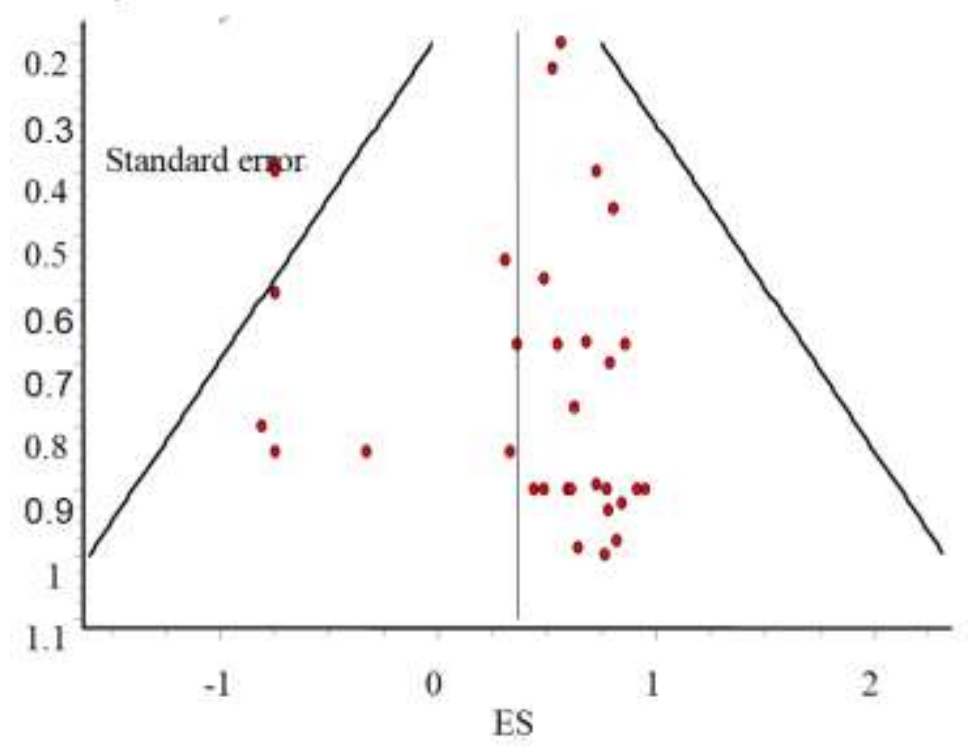

Fig 4.1.(c). A funnel plot

Source: Authors' Calculations

\subsection{Descriptive Statistics}

Table 1 below reports on the descriptive statistics of 485 coefficients of the 10 determinants of firm-level voluntary corporate disclosure extracted from 32 studies, which meet the inclusion criteria for this meta-regression analysis. 133 out of 487 observations are on firm size. Firm size has the highest number of observations and it is the most significant variable with the highest percentage of positive coefficients. In addition, most of the determinants' coefficients have a substantial percentage of significant results (i.e. $50 \%$ or more) with the exception of coefficients of leverage, ownership concentration and audit quality. In general, most of the coefficients seem to be widely dispersed from the standard deviation results, which is an indicator of substantial level of heterogeneity among the 32 studies.

Table 1. Descriptive Statistics of the ten determinants of firm-level corporate disclosure in emerging markets

\begin{tabular}{|c|c|c|c|c|c|c|c|c|c|}
\hline . & Determinants & Min & Max & Mean & $\begin{array}{l}\text { Stil. } \\
\text { Deviatien }\end{array}$ & $\begin{array}{l}\text { \% sbare of } \\
\text { significant } \\
\text { coefficients }\end{array}$ & $\begin{array}{l}\text { \% share. } \\
\text { of positive } \\
\text { significant } \\
\text { coefficients. }\end{array}$ & $\begin{array}{l}\% \text { share of } \\
\text { negative } \\
\text { significant } \\
\text { coefficients }\end{array}$ & No, of coefficients \\
\hline 1 & Firm Size & -1.309 & 25.463 & 2.570 & 4.201. & $92 \%$ & $77 \%$ & $15 \%$ & 133. \\
\hline 2 & Profitability &,- 512 & 15.213 & 0.623 & 2.568 & $55 \%$ & $42 \%$ & 1396 & 31. \\
\hline 3. & Leverage: & -14.59 & 9338 . & 0.001 & 3.204 & $49 \%$ & $34 \%$ & $15 \%$ & 68 \\
\hline 4. & $\begin{array}{l}\text { Independent } \\
\text { Directors }\end{array}$ & -0.398 & 0.333 . & 0.025 & 0.194 & $68 \%$ & $55 \%$ & $13 \%$ & 27. \\
\hline 5. & $\begin{array}{l}\text { Foreign } \\
\text { ownership. }\end{array}$ & -11.143 & 5.469 & 0.063 & 2.046 & $57 \%$ & $54 \%$ & $3 \%$ & 40. \\
\hline 6 & $\begin{array}{l}\text { Ownership } \\
\text { concentration }\end{array}$ & -11312 & 437 & $-0,626$ & 2.642 & $48 \%$ & $20 \%$ & $28 \%$ & 45 \\
\hline 7. & Board Size- & -0.490 & .537 & 0.053 . & 0.285 & $55 \%$ & $50 \%$ & $5 \%$ & 32 \\
\hline 8. & Audit Conmittee. & -0.132 & 835 & 0.212 & 0.290 & $61 \%$ & $55 \%$ & $6 \%$ & 34 \\
\hline 9. & CEO Duality & -4.272 & 685 & -0.340 & 1.147 & $53 \%$ & $11 \%$ & $42 \%$ & 45 \\
\hline 10. & Auntit Quality & -0.057 & 471 & 0.063 & 0.119. & $21 \%$ & $18 \%$ & $3 \%$ & 30. \\
\hline
\end{tabular}

Source: author's calculations 
Table 2. Meta-regression results

\begin{tabular}{|c|c|c|c|c|c|c|c|c|c|c|c|}
\hline Determinants: & Intercept & $\begin{array}{l}\text { Olysers } \\
\text { ations } \\
\text { made }\end{array}$ & $\begin{array}{l}\text { Years of } \\
\text { Observati } \\
\text { on }\end{array}$ & $\begin{array}{l}\text { Pre-ditan } \\
\text { financial } \\
\text { erisis. }\end{array}$ & $\begin{array}{l}\text { Weighting } \\
\text { of } \\
\text { dependent } \\
\text { variable }\end{array}$ & $\begin{array}{l}\text { Region } \\
\text { of study. }\end{array}$ & Panel & $\begin{array}{l}\text { Voluntary } \\
\text { disclosure }\end{array}$ & $\begin{array}{l}\text { Nen-fina } \\
\text { ncial } \\
\text { firma }\end{array}$ & $\mathbf{R}^{2}$ & $\begin{array}{l}\text { No, of } \\
\text { observ } \\
\text { atiens. }\end{array}$ \\
\hline Finm size & $\begin{array}{l}-0.259 \\
(1.214)\end{array}$ & $\begin{array}{l}-0.002 \\
(0.003)\end{array}$ & $\begin{array}{l}-0.140 \\
(0.139)\end{array}$ & $\begin{array}{l}-0.330 \\
(0.345)^{\circ 4} .\end{array}$ & $\begin{array}{l}0.155 \\
(0.892)\end{array}$ & $\begin{array}{l}0.514 . \\
(0.883)\end{array}$ & $\begin{array}{l}2.186 \\
(1.61)\end{array}$ & $\begin{array}{l}0.0013 \\
(0.812)\end{array}$ & $\begin{array}{l}0.656 \\
(0.865)\end{array}$ & 0208 & 153 \\
\hline Protitability & $\begin{array}{l}-0.229 \\
(0.618)\end{array}$ & $\begin{array}{l}-0.0001- \\
(0.00 t)\end{array}$ & $\begin{array}{l}0.004 \\
(0.015)\end{array}$ & $\begin{array}{l}0.327 \\
(0.300)\end{array}$ & $\begin{array}{l}-0.029 \\
(0.145)\end{array}$ & $\begin{array}{l}-0.315 * 0 \\
(0.122)\end{array}$ & $\begin{array}{l}0.4720 \\
(0.434)\end{array}$ & $\begin{array}{l}-0.550 \\
(0.176)\end{array}$ & $\begin{array}{l}-0.013 \\
\langle 0.131)\end{array}$ & 0.374 & 35. \\
\hline Leverage & $\begin{array}{l}-0.047 \\
(0.446)\end{array}$ & $\begin{array}{l}0.000 \\
(0.001)\end{array}$ & $\begin{array}{l}0.058 \\
(0.041)\end{array}$ & $\begin{array}{l}0.112 \\
(0.390)\end{array}$ & $\begin{array}{l}0.028 \\
(0.266)\end{array}$ & $\begin{array}{l}-0.012^{* *} \\
(0.006)\end{array}$ & $\begin{array}{l}-0.142 \\
(0.299)\end{array}$ & $\begin{array}{l}-0.497 \\
(0,71)\end{array}$ & $\begin{array}{l}0.134 \\
(0.277)\end{array}$ & 0.182 & 65. \\
\hline Boord Independence- & $\begin{array}{l}12.436 \% \\
(0.781)\end{array}$ & $\begin{array}{l}0.002 \\
(0.001)\end{array}$ & $\begin{array}{l}-0.300 * 0 . \\
(0.076)\end{array}$ & $\begin{array}{l}3.624^{* 0} \\
(1.034)\end{array}$ & $\begin{array}{l}0.979 \times 4, \\
(0.375)\end{array}$ & $\begin{array}{l}1.629^{* *}, \\
(0.451)\end{array}$ & $\begin{array}{l}-0.820 \\
(0.489)\end{array}$ & $\begin{array}{l}1.141^{* 0} \\
(0.397)\end{array}$ & $\begin{array}{l}-0.362 \\
(0.348)\end{array}$ & 0.750 & 31. \\
\hline Forengn L isting Stahis. & $\begin{array}{l}3.947^{* *}, \\
(6.211)\end{array}$ & $\begin{array}{l}0.002 \\
(0.005)\end{array}$ & $\begin{array}{l}0.256^{* 0}, \\
(0.025)\end{array}$ & $\begin{array}{l}0.979 * * \\
(0.136)\end{array}$ & $\begin{array}{l}-3.452 * 0, \\
(0.176)\end{array}$ & $\begin{array}{l}4.766^{\circ *} \\
(0.194)\end{array}$ & $\begin{array}{l}0.527 * \% \\
(0.148)\end{array}$ & $=$ & $\approx$ & 0.963. & 40. \\
\hline Ownershipeoncentration & $\begin{array}{l}-4.238 * 4, \\
(0.229)\end{array}$ & $\begin{array}{l}0.094 \\
(0.078)\end{array}$ & $\begin{array}{l}-1558 * 0 \\
(0.069)\end{array}$ & $\begin{array}{l}11.876^{* 0} \text {. } \\
(0.804)\end{array}$ & $\begin{array}{l}14,436 * 6 \\
(0.703)\end{array}$ & $\begin{array}{l}0.748^{* *} \\
(0.253)\end{array}$ & $\alpha$ & - & $\approx$ & 0.903. & 35. \\
\hline Board Size. & $\begin{array}{l}0.509^{* *} \\
(1083)\end{array}$ & $\begin{array}{l}-0.001 \text {. } \\
(0.001)\end{array}$ & $\begin{array}{l}-0.11^{* *} \\
(0.012)\end{array}$ & $\begin{array}{l}0.848 * 0 \\
(0.159)\end{array}$ & $\begin{array}{l}-0.280^{* *}, \\
(0.043)\end{array}$ & $\begin{array}{l}0.171^{* *} \\
(0.061)\end{array}$ & $\begin{array}{l}0.185 \% 4, \\
(0.057)\end{array}$ & - & $\approx$ & 0.840 & 32. \\
\hline Andit Conminitee- & $\begin{array}{l}0.336 * * \\
0.0759\end{array}$ & $\begin{array}{l}0.001 \\
(0.002)\end{array}$ & $\begin{array}{l}0.624^{* *}, \\
(0.032)\end{array}$ & $\begin{array}{l}0.585 * 0 \\
0.035)\end{array}$ & $\begin{array}{l}-0.711 \% \\
(0.036)\end{array}$ & $\begin{array}{l}0.764^{* *} \\
(0.042)\end{array}$ & $\begin{array}{l}0.700 \% \\
(0.043)\end{array}$ & $\begin{array}{l}0.458 * 0, \\
(0.055)\end{array}$ & $\begin{array}{l}-0.612 \\
(0.072)\end{array}$ & 0.900 & 34. \\
\hline CEODuatity & $\begin{array}{l}-3.608 * 4 \\
(0.107)\end{array}$ & $\begin{array}{l}-0.008 \\
(0.015)\end{array}$ & $\begin{array}{l}-1000 * \\
(0.039)\end{array}$ & $\begin{array}{l}9.188^{* 4} \\
(0.263)\end{array}$ & $\begin{array}{l}-0.017 . \\
(0.148)\end{array}$ & $\begin{array}{l}1.133^{* *} \\
(0.132)\end{array}$ & $\begin{array}{l}-1.910^{4 *} \text {, } \\
(0.193)\end{array}$ & - & - & 0982 & 45. \\
\hline Andit Quality: & $\begin{array}{l}0.36 * 0 \\
(0.077)\end{array}$ & $\begin{array}{l}0.001=4 \\
(0.002)\end{array}$ & * & $\begin{array}{l}0.624^{\circ} \\
0.032)\end{array}$ & $\begin{array}{l}-0.964 * 4 \\
(0.033)\end{array}$ & $\begin{array}{l}0.611^{* *} \\
(0.036)\end{array}$ & $\begin{array}{l}0.709 * 4 \\
(0.043)\end{array}$ & $\begin{array}{l}0.458 *+ \\
(0.055)\end{array}$ & $\begin{array}{l}-0.642^{*+} \\
(0.072)\end{array}$ & 0.898 & 36 \\
\hline
\end{tabular}

Notes: Table 2 reports on beta coefficients of the control variables (i.e firm characheristics) against the depend variable effect sizes for ten meta-regression of the determinants of voluntary corporate disclosure in emerging markets; using restricted random maximum likelihood (REML). The numbers in parentheses are robust standard errors, and $* *$ denotes significance at $5 \%$ level

\subsection{Regression Results}

Table 2 above provides regression results of the ten meta-regression models. Robust standard errors (i.e. numbers in parentheses) are used to test for the significance of the study hypotheses. The effect of study characteristics is examined through individual coefficients. Moreover, the researcher tested for multicollinearity for each regression line and omitted any moderator variables that showed high dependence in that particular meta-regression.

The results show that board independence, foreign listings, ownership concentration, board size, audit committee, CEO duality, and audit quality are significant determinants of voluntary corporate disclosure in emerging countries. However, firm size, profitability, and leverage are not significant. Furthermore, the most robust and significant determinants of voluntary corporate disclosure practices in emerging countries are board independence and foreign listing status. This implies that if such firms have a significant ratio of independent directors in their boards and/ or these are listed on foreign stock exchanges, then these firms are expected to have a high-level of corporate disclosure.

Contrary to this, descriptive statistics show that the firms' size is identified as the major determinant of firm level corporate disclosure in emerging economies by most empirical studies. The intercept for firm size in this meta-regression results is insignificant contrasting the meta-analyses of Ahmed (1998), Ahmed and Courtis (1999) and Khlif and Souissi (2010) who identify firm size as a significant determinant of corporate disclosure. 
In the meta-regression model for firm size, the pre-Asian financial crisis period variable is negative and significant while the region of the study variable is positive and significant. This implies that after the Asian financial crisis of 1997, corporate disclosure requirements became important for all firms regardless of the size. Therefore, this is a plausible explanation on why firm size is not a significant determinant of corporate disclosure in Asia after the Asian financial crisis.

For the other determinants, similar to Khlif, Ahmed and Souissi (2016), the analyses of this study show that foreign listing has a positive effect but ownership concentration has a negative effect on voluntary corporate disclosure. Moreover, (with the exception of leverage and profitability), the pre-Asian financial crisis period variable is significant and positive. This means that these determinants have the same effect on corporate disclosure practices in emerging markets located in Asian countries before and after the Asian financial crisis of 1997. The region of the study variable is positive and significant for all ten determinants as most Asian countries are located in emerging markets.

Results of the meta-regression show that audit quality is a significant determinant of corporate disclosure. This is consistent with the findings of Ahmed (1998), Khlif and Souissi (2010). Moreover, audit quality is affected by study characteristics the most. All study characteristics (e.g. observations made, weighting of dependent variable, region of study, and voluntary disclosure) are significant for this determinant. This implies that results relating to this determinant in the original empirical researches in emerging markets are heterogeneous due to the effects of study characteristics on the results.

In addition, both leverage and profitability show negative and insignificant coefficients. Further analysis on the effect of study characteristics on these two determinants reveals that the variable for region of the study is negative and significant. Since the variable region of the study is defined with respect to the Asian continent, it is thus an indication that profitability and leverage are insignificant only in emerging countries located in Asia. According to Claessens and Kose (2013), leverage, for example, may not be significant in Asian countries because firms in this region value internal/ family financing than external financing. In fact, region of the study is the only study characteristic that has turned out significant for these two determinants as a further evidence that these two determinants are not relevant in this region.

Another study characteristic that are found to have a significant effect on results is weighting of a dependent variable. Voluntary corporate disclosure index score is employed as a dependent variable in these studies. Theory and empirical evidence provide mixed conclusion on whether weighting/non-weighting of corporate disclosure index may or may not distort results (e.g. Coombs \&Tayib, 1998; and Fathi, 2013). For this current study, it is concluded that when corporate disclosure index is weighted, results in the original empirical researches are affected. Hence, un-weighting corporate disclosure index is recommended.

On the other hand, study characteristics that do not have any significant effect on original empirical researches include non-financial firms variable, voluntary disclosure variable and number of observations variable. Non-financial firms variable is not significant in emerging 
countries because requirements for corporate disclosure for non-financial firms have become as strict as disclosure requirements for financial firms in emerging markets due to financial crises and a series of collapse of some of the most successful companies in emerging countries.

Further, this study concludes that the definition of corporate disclosure index, i.e. whether voluntary or non-voluntary, has no effect on results. The number of firms/observations used as sample size in the original studies did not to have any significant effect on the heterogeneity in the study results.

Overall, study characteristics that have a major effect on the original empirical studies from the meta-regression results include financial crisis variable, region of the study variable, and the variable for weighting of dependent variable.

\section{Conclusions}

The empirical results show that the most important and robust determinants of corporate disclosure in emerging markets are board independence and foreign listing status. Further, based on this study results, it is concluded that firm size is not a significant determinant of corporate disclosure in emerging markets.

The novel contribution to knowledge of this study is its extension to literature relating to corporate disclosure practice in emerging countries, which are still failing to implement successfully, appropriate corporate disclosure mechanisms. Secondly, this is the first meta-regression study that examines the factors, which determine corporate disclosure in emerging markets. This study resolves the ambiguity that has existed over the past decade in literature as to which factors are really important and robust in the practice of corporate disclosure in emerging markets.

Despite its significance, this study has several limitations that should be taken into consideration when interpreting the results. First, most of the studies in the sample are based in emerging countries located in the Asian continent. This is because most emerging economies are found in Asia. Secondly, only studies that used multiple regression methodology have been included in order to avoid introducing more heterogeneity.

\section{References}

Ahmed, K. (1998). The Effect of corporate characteristics on disclosure quality in corporate annual reports: A Meta-Analysis.

Ahmed, K., \& Courtis, 1. (1999). Associations between corporate characteristics and disclosure levels in annual reports: A Meta-analysis, British Accounting Review, 31(1), 35-61.

Adelepo, I. (2011). Voluntary disclosure practices among listed companies in Nigeria. Advances in Accounting, 27, 338-345.

Ahmed, K., \& Courtis, J. (1999). Associations between corporate characteristics and disclosure levels in annual reports: A meta-analysis. British Accounting Review, 31, 35-61. https://doi.org/10.1006/bare.1998.0082 
Almadi, M. M. (2015). Organizational governance, board of directors, and the influence of context in emerging markets. International Business Research, 10(12), 116-126. https://doi.org/10.5539/ijbm.v10n12p116

Abeywardana, N. E., \& Panditharathna, K. M. (2016). The Extent and Determinants of Voluntary Disclosures in Annual Reports: Evidence from Banking and Finance Companies in Sri Lanka. Accounting and Finance Research. https://doi.org/10.5430/afr.v5n4p147

Akhtaruddin, M. \& Rouf, M. (2018). Corporate governance, cultural factors and voluntary disclosure: Evidence from selected companies in Bangladesh. Corporate Board: Role, 8(1), 48-61. https://doi.org/10.22495/cbv8i1art4

Ankamah-Yeboah, I., \& Rehdanz, K. (2014). Explaining the variation in the value of building energy efficiency certificates; a quantitative meta-analysis, Kiel Working Paper, No. 1949, Kiel Institute for the World Economy (lfW), Kiel.

Al-Janadi, Y., Rahman, A., \& Omar, N. (2013). Corporate governance mechanisms and voluntary disclosure in Saudi Arabia, Research Journal of Finance and Accounting, 4(4), 25-35. https://doi.org/10.6007/IJARAFMS/v10-i2/7440

Alturki, K. (2014). Voluntary disclosure by Saudi companies, Research Journal of Finance and Accounting, 5(20), 77-94.

Anggraini, R., \& Gurendrawati, Y. (2015). Firm size, ownership concentration and the business sector, the influence to credit access SMEs in Indonesia, International journal of finance and accounting, 4(5), 231-235.

Altawalbeh, M. (2020). Audit Committee Attributes, Corporate Governance and Voluntary Disclosure: Evidence from Jordan, International Journal of Academic Research in Accounting, Finance and Management Sciences, 10(2), 243-253.

Bhasin, M. L. (2013). Corporate governance and forensic accountant: An exploratory study. Journal of Accounting, Business \& Management, 20, 55-83.

Biswas, P. K. (2013). Corporate Governance Reforms in Emerging Countries: A Case Study of Bangladesh. International Journal of Disclosure and Governance, 12(1). https://doi.org/10.1057/jdg.2013.31

Bokpin, G. A. (2013). Determinants and value relevance of corporate disclosure. Journal of Applied Accounting Research, 14(2), 127-146. https://doi.org/10.1108/09675421311291883

Boubaker, S., \& Nguyen, D. (2014) (eds). Corporate governance in emerging markets: theories, practices and cases. http://www.springer.com/978-3-642-44954-3

Chakroun, R., \& Matoussi, H. (2012). Determinants of the extent of voluntary disclosure in the annual reports of the Tunisian firms, Accounting and Management Information Systems. $11(3), 335-370$.

Chantachaimongkol, N., \& Chen, S. (2018). The influence of corporate governance attributes and national characteristics on information disclosures: a case of ASEAN, European Journal 
of Accounting and Finance Research, 6(5), 47-72.

Charumathi, B., \& Ramesh, R. (2015). On the determinants of voluntary disclosure by Indian companies, Asian-Pacific Journal of Management Research and Innovation, 11(2), 108-116. https://doi.org/10.1177/2319510X15576179

Cheng, Q. (2014). Family firm research- a review, China Journal of Accounting Research, 7(3), 149-163. https://doi.org/10.1016/j.cjar.2014.03.002

Claessens, S., \& Kose, A. (2013). Financial crises: review and evidence. Central Bank Review, 13, 1-23. https://doi.org/10.5089/9781475561005.001

Clarke, T. (2015). Changing paradigms in corporate governance: new cycles and new responsibilities, Society and Business Review, 10(3), 306-326. https://doi.org/10.1108/SBR-07-2015-0027

Coombs, H., \& Tayib, M. (1998). Developing a disclosure index for local authority published accounts: A comparative study of local authority published financial reports between the UK and Malaysia, paper presented at the 2nd Asian Pacific interdisciplinary research in accounting conference, Osaka, Japan.

Damagum, Y., \& Chima, E. (2013). The impact of corporate governance on voluntary information disclosures of quoted firms in Nigeria: An empirical analysis, Research Journal of Finance and Accounting, 4(13).

Cuaresma, J. C., Hlouskova, J., \& Obersteiner, M. (2008). Natural disasters as creative destruction? Evidence from developing countries. Econ. Inquiry, 46, 214-226. https://doi.org/10.1111/j.1465-7295.2007.00063.x

Desoky, A., \& Mousa, G. (2012). Corporate governance practices: Transparency and disclosure-evidence from the Egyptian exchange. Journal of Accounting, Finance and Economics, 2(1), 49-72.

Doi, S. A., \& Thalib, L. (2008). A quality-effects model for meta-analysis. Epidemiology, 19(1), 94-100. https://doi.org/10.1097/EDE.0b013e31815c24e7

Dembo, A. M., \& Rasaratnam, S. (2014). Corporate governance and disclosure in Nigeria: An empirical study. Procedia - Social and Behavioral Sciences, 161-171. https://doi.org/10.1016/j.sbspro.2014.11.064

Desta, I., Bishagazi, P. K, \& Kifle, T. (2019). Industry Characteristics and Voluntary Disclosure in Private Mining and Manufacturing Firms in Tanzania, Journal of Developing Areas, Tennessee State University, College of Business, 53(3), 141-154, Summer. https://doi.org/10.1353/jda.2019.0043

Elfeky, M. I. (2017). The extent of voluntary disclosure and its determinants in emerging markets: Evidence from Egypt. The Journal of Finance and Data Science, 3(1-4), 45-59. https://doi.org/10.1016/j.jfds.2017.09.005

Elkhishin, S., \& Mohieldin, M. (2020). External debt vulnerability in emerging markets and 
developing economies during the COVID-19 shock, Emerging markets and developing economies. https://doi.org/10.2139/ssrn.3703472

Fathi, J. (2013). Corporate governance and the level of financial disclosure by Tunisian firm, Journal of Business Studies Quarterly, 4(2), 95-111.

Forker. J. (1992). Corporate governance and disclosure quality, Accounting and Business Research, 22(86), 111-124. https://doi.org/10.1080/00014788.1992.9729426

Foyeke, O., Odianonsen, I., \& Aanu, O. (2015). Firm size and financial performance: A determinant of corporate governance disclosure practices of Nigerian companies, Journal of Accounting and Auditing: Research and Practice. https://doi.org/10.5171/2015.467294

Ghasempour, A., \& Yusof, M. (2014). The effect of fundamental determinants on voluntary disclosure of financial and nonfinancial information: the case of Tehran stock exchange, Accounting and Marketing, 2(1). https://doi.org/10.4192/1577-8517-v14_2

Geddes, B. H. (2020). Agency Theory, Accounting Based Performance Evaluation Systems and IFRS: A Brief Relational Overview. Journal of Economics and Business, 3(3). https://doi.org/10.31014/aior.1992.03.03.271

Hashim, M. H., Nawawi, A., \& Salin, A. A. (2014). Determinants of Strategic Information Disclosure - Malaysian Evidence. International Journal of Business, 547-572.

Huber, D. W., \& DiGabriele, J. A. (2021). Corporate governance and disclosure: purpose, scope, and limitations. International Journal of Disclosure and Governance, Palgrave Macmillan, 18(2), 153-160. https://doi.org/10.1057/s41310-021-00103-7

Haji, A., Mohd, G., \& Nazli, A. (2012). The influence of the financial crisis on corporate voluntary disclosure: Some Malaysian evidence, International Journal of Disclosure and Governance, 9(2), 101-125. https://doi.org/10.1057/jdg.2011.27

Hedges, L. V., Tipton, E., \& Johnson, M. C. (2010). Robust Variance Estimation in Meta-Regression With Dependent Effect Size Estimates. Research Synthesis Methods, 1(1), 39-65. https://doi.org/10.1002/jrsm.5

Jensen, M. C., \& Meckling, W. H. (1976). Theory of the firm: managerial behavior, agency costs and ownership structure, Journal of Financial Economics, 3(4), 305-360. https://doi.org/10.1016/0304-405X(76)90026-X

Ji, X., Ahmed, K., \& Lu, W. (2015). The impact of corporate governance and ownership structure reforms on earnings fality in China, International Journal of Accounting and Information Management, 23(2), 169-198. https://doi.org/10.1108/IJAIM-05-2014-0035

Jouirou, M., \& Chenguel, M. (2014). The determinants of voluntary disclosure in Tunisia: A study of the firms listed in the Tunisian Stock Exchange, Journal of Business, and Management Research, 4, 86-97.

Khaldoon, A. (2015). Corporate governance and voluntary disclosure evidence from Jordan, European academic research, 2(10), 13197-13214. 
Khlif, H., \& Souissi, M. (2010). The determinants of corporate disclosure: a meta-analysis, International Journal of Accounting and Information Management, 18(3), 198-219. https://doi.org/10.1108/18347641011068965

Khlif, H., Ahmed, K., \& Souissi, M. (2016). Ownership structure and voluntary disclosure: a synthesis of empirical studies. Australian Journal of Management, 42(3), 376-403. https://doi.org/10.1177/0312896216641475

Kim, J. M., Taylor, D. J., \& Robert, E. V. (2021). Voluntary disclosure when private information and disclosure costs are jointly determined, Review of Accounting Studies. https://doi.org/10.2139/ssrn.3595320

Kolsi, M. C. (2012). The determinants of corporate voluntary disclosure: Evidence from the Tunisian capital market, The IUP Journal of Accounting Research \& Audit Practices, 11(4), 49-68.

Lan, Y., Wang, L., \& Zhang, X. (2013). Determinants and features of voluntary disclosure in the Chinese Stock market. China Journal of Accounting and Research, 6(1), 265-285. https://doi.org/10.1016/j.cjar.2013.04.001

Lee, D., Lee, S., \& Na-Eun, C. (2019). Voluntary Disclosure and Market Valuation of Reports in Korea: The Case of Chaebols. Sustainability, 11, 1-20. https://doi.org/10.3390/su11133577

Lokman, N., Cotter, J., \& Mula, J. (2012). Corporate governance quality, incentive factors, and voluntary corporate governance disclosures in annual reports of Malaysian publicly listed companies. Corporate Ownership and Control, 10, 329-352. https://doi.org/10.22495/cocv10i1c3art3

Lokman, N., Mula J. M., \& Cotter, J. (2014). Importance of corporate governance quality and voluntary disclosures of corporate governance information in listed Malaysian family controlled businesses. International Journal of Sustainable Development \& World Policy, $3(1), 1-24$.

Masum, M. H., Latiff, A. R., \& Osman, M. N. (2020). Determinants of corporate voluntary disclosure in a transition economy. Problems and Perspectives in Management, 18(4), 130-141. https://doi.org/10.21511/ppm.18(4).2020.12Murcia, A., \& Santos, A. (2012). Discretionary-based disclosure: evidence from the Brazilian market. BAR, Rio de Janeiro, 9(1), 88-109. https://doi.org/10.1590/S1807-76922012000100006

Nejla, O., \& Haitham, N. (2017). Corporate risk disclosure of Islamic and conventional banks. Banks and Bank Systems, 12(3), 247-256. https://doi.org/10.21511/bbs.12(3-1).2017.09

Neifar, S., \& Halioui, K. (2013). Determinants of corporate governance disclosure: The case of Tunisian firms listed on the Tunis Stock Exchange. International Journal of Finance and Accounting, 2(3), 174-183.

Neifar, S., \& Jarboui, A. (2018). Corporate governance and operational risk voluntary disclosure: Evidence from Islamic banks. Research in International Business and Finance, 46, 43-54. https://doi.org/10.1016/j.ribaf.2017.09.006 
Ntim, C. G., Opong, K. K., Danbolt, J., \& Thomas, D. M. (2012). Voluntary corporate governance disclosures by post-apartheid South African corporations. Journal of Applied Accounting Research, 13(2). https://doi.org/10.1108/09675421211254830

Panditharathna, K. M. (2019). Corporate Governance and Voluntary Disclosure Level: Evidence from Manufacturing Companies In Sri Lanka. International Journal of Scientific and Research Publications, 9(12), 720-730. https://doi.org/10.29322/IJSRP.9.12.2019.p9691

Qu, W., Philomena L., \& Barry, C. (2013). A study of voluntary disclosure of listed Chinese firms - a stakeholder perspective. Managerial-auditing journal, 28(3), 261-294. https://doi.org/10.1108/02686901311304376

Rezaee, Z. L. T. (2017). Are the quantity and quality of sustainability disclosures associated with the innate and discretionary earnings quality? Journal of Business Ethics, April 2017, In Press. https://doi.org/10.1007/s10551-017-3546-y

Rouf, M. A. (2011). An Empirical investigation into corporate voluntary disclosure of management's responsibilities in the Bangladeshi listed companies, ASA University Review, 5(1), 261-274.

Rukhin, A., Soto, J., Nechvatal, J., Smid, M., \& Barker, E. (2001). A Statistical Test Suite for Random and Pseudorandom Number Generators for Cryptographic Applications, NIST Special Publication 800-22. Technical report, Booz-Allen and Hamilton Inc Mclean Va. https://doi.org/10.6028/NIST.SP.800-22

Sarhan, A. A., \& Ntim, C. G. (2019). Corporate boards, shareholding structures and voluntary disclosure in emerging MENA economies. Journal of Accounting in Emerging Economies, 9(1), 2-27. https://doi.org/10.1108/JAEE-03-2017-0033

Stanley, D., \& Doucouliagos, H. (2019). Practical Significance, Meta-Analysis and the Credibility of Economics. Working Paper (IZA DP No. 12458). IZA Institute of Labor Economics. https://doi.org/10.2139/ssrn.3427595

Stanley, T. D., \& Jarrell, S. B. (1989) Meta-regression analysis: A quantitative method of literature surveys. Journal of Economic Surveys, 3, 161-170. https://doi.org/10.1111/j.1467-6419.1989.tb00064.x

Tandiono, R., \& Hutagaol-Martowidjojo, R. (2013). Profile of voluntary disclosure of family business in Indonesia: An exploratory study. Proceedings of 4th Asia-Pacific business research conference 30 September-1 October 2013, bay view hotel, Singapore ISBN: 978-1-922069-31-3.

Williams, R. T. (2012). Using Robust Standard Errors to Combine Multiple Regression Estimates with Meta-Analysis. Doctoral Dissertation

Vu, K. A., Tower, G., \& Scully, G. (2011). Corporate communication for Vietnamese listed firms, Asian Review of Accounting, 19(2), 125-146. https://doi.org/10.1108/13217341111181069 


\section{Copyright Disclaimer}

Copyright for this article is retained by the author(s), with first publication rights granted to the journal.

This is an open-access article distributed under the terms and conditions of the Creative Commons Attribution license (http://creativecommons.org/licenses/by/4.0/). 